\title{
The Student Wheels Strategy in Teaching Speaking Skills to Cultivate Politeness at Junior High School
}

\author{
Nanik Mariani Effendie* \\ English Department FKIP Lambung Mangkurat University Banjarmasin, South Kalimantan, Indonesia \\ *Corresponding author: nanikmariani59@yahoo.com
}

Received October 27, 2014; Revised November 22, 2014; Accepted December 15, 2014

\begin{abstract}
The English Course is one of the foreign language courses that must be taught as a compulsory subject at school, especially in the Junior High School. It is more stressed on knowledge of the four standards of competence or the four language skills, without considering the ethical values contained in that four language skills. It means that the teaching and learning English, especially in speaking skills, should be taught not only in the cognitive skills, but also in the affective skills as well. The education regarding how language-speaking politely, considering the value of tolerance, sympathy, and empathy. So implementing politeness in the process of teaching English speaking skills is important. Politeness is the rules of conduct established and agreed upon jointly by a particular community so that politeness as well as be concluded by the prerequisite of social behavior. To cultivate politeness in English speaking class, the English teachers at Junior High Schools (SMP) can use the teaching strategy, such as Student wheels strategy. Student Wheels is adopted from Hadfield (in Sulistiyowati, 2009: 72-73) to get the students more active in speaking class and accustomed in using polite language. Using Student wheels, all students can get their roles in speaking because they have to interact each other by standing in two circles formed as wheels. In this strategy, all students use the expressions of English speaking thought by the teacher and they can accustom by themselves in implementing politeness in the classroom.
\end{abstract}

Keywords: politeness, student wheels, English speaking class

Cite This Article: Nanik Mariani Effendie, "The Student Wheels Strategy in Teaching Speaking Skills to Cultivate Politeness at Junior High School.” American Journal of Educational Research, vol. 2, no. 12 (2014): 1211-1217. doi: 10.12691/education-2-12-13.

\section{Introduction}

Education is one important aspect of nation building. When the East Asian countries appeared new industries, many experts declared that the successful of development of these countries are supported by the availability of many educated people. Therefore, almost all nations put the development of education as a priority in their national development programs. The quality of human resources, which have good education, is the key to successful development of a country.

A formal education is done at school in Indonesia and it has some subjects taught to the students, such as Mathematical and Natural Sciences, Social Studies, Indonesian language, and foreign languages. One of the foreign languages learned by the students is English.

English becomes the most essential language in the world. Almost all the people from many different countries around the world use English to communicate. English is one of the foreign languages for Indonesian students, which should be learnt in school since Elementary until University. English is considered as a difficult subject for the Indonesian students, because English is completely different from Indonesian language based on its grammar, pronunciation, and vocabulary.
English learning presented at Junior High School (SMP) is more stressed on knowledge of the four standards of competence or the four language skills, such as, Listening, Speaking, Reading, and Writing, without considering the ethical values contained in that four language skills. It means that the teaching and learning English, especially in speaking skills, should be taught not only in the cognitive skills, but also in the affective skills as well. Muslich (2006:1) stated that politeness, courtesy, or etiquette is a procedure, custom, or custom prevailing in the society. Politeness is the rules of conducting established and agreed upon jointly by a particular community so that politeness as well as be concluded by the prerequisite of social behavior.

Teaching English speaking skills means to teach students to produce the English speech sounds, and sound pattern, using word and sentence stress, intonation pattern and the rhythm of the foreign language, select appropriate words and sentence according to the proper social setting, situations and object matter, organize their taught in a meaningful and logical sequence, use language as means of expressing values and judgments, use the language quickly and confidently with few unnatural pauses, which is called as fluency. Meanwhile, learning speaking means the activity of students to get knowledge of make use of words to communicate in appropriate situation in order to improve their knowledge. 
The education regarding how language-speaking politely, considering the value of tolerance, sympathy, and empathy. So the cognitive and affective skills must be balanced. For example, implementing politeness in the process of teaching English speaking skills.

\section{Problems Identification}

Based on the expression on the backgound of study above, the writer wants to describe that the process of teaching and learning English at school, from elementary to university, is still focused on the knowledge of English as in standard competence of English Syllabus and English language components without considering their ethical values. It might be of the lack of teachers' knowledge about the language of politeness theories and how to implement it in their teaching. Therefore, the writer wants to try to assess how the ethical values or the politeness of English taught or implemented at schools, especially in the classroom.

Actually the standard competence and based competence of English syllabus used by Junior high school has already been contained of ethical values, especially in teaching speaking skill, which has politeness expressions in it. But it is not implemented as well because it's taught the knowledge how to express the terms in conversation only.

In cultivating politeness in students' behaviour during the teaching and learning English speaking process can be done by using some strategies. One of the strategies can be used in teaching English, especially in English speaking skills is Student wheels strategy. The student wheels strategy is adopted from Hadfield (in Sulistiyowati, 2009: 72-73) to get the students more active in speaking class and accustomed in using polite language. By using student wheels strategy, all students can get their roles in speaking because they have to interact each other by standing in two circles formed as wheels. In this strategy, all students use the expressions of English speaking thought by the teacher and they can accustom by themselves in implementing politeness in the classroom.

\subsection{Statement of the Research Problems}

2.1.1. How the implementation of student wheels strategy can improve the students' ability in English speaking skills?

2.1.2. How the implementation of student wheels strategy can cultivate politeness to the students' speaking skills?

\subsection{Objective of the Study}

2.2.1. To improve the students' ability in English speaking skill by implementing the student wheels strategy.

2.2.2. To cultivate the students' politeness in English speaking skills by implementing the student wheels strategy.

\section{Literature Review}

\subsection{Ethics of Language}

Chaer (2010:6) states that the ethics of language is relating to speech act behavior or to speaking behavior. Acoording to Masinambouw (1984:6), the language system has a function as a means of human interaction in a society that has norms which applied in that culture. Meanwhile, according to Geertz (1976) in Chaer (2010:6) that the system of speech acts behavior in that cultural norms is called ethics of language.

The ethics of speaking is closely related to social norms and cultural systems that apply in a society. So, the ethics of speaking will arrange us in: (a) what should a speaker say to a hearer at the certain time based on the social and cultural status applied on the society, (b) register of languages used in the time and particular culture; (c) when and how we use our turn to speak and interrupt or how interrupting the other speech, (d) when we should be silent, to hear the speech, and (e) how we should arrange our voice, to be loud, slowly, or rising, and how our physical attitudes or gestures should be in that speaking. Someone can be said that he is a language proficiency if he can master the precedure and the ethics of the language as well.

English does not have the difference terms to call an older people shown to be more respected or ethics but it's more directed at the use of language, words choices, the use of correct pronunciation, the stress placement, and the use of intonation correctly based on the speech situation. For example, we could use the word 'would' instead of the word 'will' to show more polite situation as "Will you clean the board" or to be more polite by "Would you like to clean the board please".

\subsection{Politeness}

Polite behaviour is equivalent to socially 'correct' or appropriate behaviour: other consider it to be the hallmark or the cultivated man or woman. Some might: characterise a polite person as always being considerate towards other people: others might suggest that a polite person is selfeffacing. To characterise polite language usage, we might resort to expressions like 'the language a person uses to avoid being too direct', or 'language which displays respect towards or consideration for others'. Once again, we might give examples, such as 'language which contains respectful form of address like Sir or Madam', 'language that displays certain "polite" formulaic utterances, like please, thank you, excuse me, or sorry' or even 'elegantly expressed language' (Watts, 2003: 1-2).

In everyday conversation, there are ways to go about getting the things we want. When we are with a group of friends, we can say to them, "Go get me that plate!", or "Shut-up!" However, when we are surrounded by a group of adults at a formal function, in which our parents are attending, we must say, "Could you please pass me that plate, if you don't mind?" and "I'm sorry, I don't mean to interrupt, but I am not able to hear the speaker in the front of the room." In different social situations, we are obligated to adjust our use of words to fit the occasion. It would seem socially unacceptable if the phrases above were reversed.

According to Brown and Levinson, politeness strategies are developed in order to save the hearers' "face." Face refers to the respect that an individual has for him or herself, and maintaining that "self-esteem" in public or in private situations. Usually you try to avoid embarrassing 
the other person, or making them feel uncomfortable. Face Threatening Acts (FTA's) are acts that infringe on the hearers' need to maintain his/her self esteem, and be respected. Politeness strategies are developed for the main purpose of dealing with these FTA's. What would you do if you saw a cup of pens on your teacher's desk, and you wanted to use one, would you;

a. say, "Ooh, I want to use one of those!"

b. say, "So, is it O.K. if I use one of those pens?"

c. say, "I'm sorry to bother you but, I just wanted to ask you if I could use one of those pens?"

d. Indirectly say, "Hmm, I sure could use a blue pen right now."

There are four types of politeness strategies, described by Brown and Levinson that sum up human "politeness" behavior: Bald on-Record, Negative Politeness, Positive Politeness, and Off-Record-indirect strategy. They are:

\subsubsection{Bald on-record}

These provide no effort by you to reduce the impact of the FTA's. You will most likely shock the person to whom you are speaking to, embarrass them, or make them feel a bit uncomfortable. However, this type of strategy is commonly found with people who know each other very well, and are very comfortable in their environment, such as close friends and family. For example:

a. An Emergency: HELP!!

b. Task oriented: Give me that!

c. Request: Put your coat away.

d. Alerting: Turn your headlights on! (When alerting someone to something they should be doing)

\subsubsection{Positive Politeness}

It is usually seen in groups of friends, or where people in the given social situation know each other fairly well. It usually tries to minimize the distance between them by expressing friendliness and solid interest in the hearer's need to be respected (minimize the FTA). For example:

a. Attend to the hearer: "You must be hungry, it's a long time since breakfast. How about some lunch?"

b. Avoid disagreement: A: "What is she, small?" B: "Yes, yes, she's small, smallish, um, not really small but certainly not very big."

c. Assume agreement: "So when are you coming to see us?"

d. Hedge opinion: "You really should sort of try harder."

\subsubsection{Negative Politeness}

The main focus for using this strategy is to assume that you may be imposing on the hearer, and intruding on their space. Therefore, these automatically assume that there might be some social distance or awkwardness in the situation. For example:

a. Be indirect: "I'm looking for a comb." In this situation you are hoping that you will not have to ask directly, so as not to impose and take up the hearer's time. Therefore, by using this indirect strategy, you hope they will offer to go find one for you.

b. Forgiveness: "You must forgive me but...."

c. Minimize imposition: "I just want to ask you if I could use your computer?" d. Pluralize the person responsible: "We forgot to tell you that you needed to by your plane ticket by yesterday." This takes all responsibility off of only you and onto "we", even if you were the person responsible for telling the hearer when the deadline was to buy the ticket.

\subsubsection{Off-Record (indirect)}

You are removing yourself from any imposition whatsoever. For example:

a. Give hints: "It's cold in here."

b. Be vague: "Perhaps someone should have been more responsible."

c. Be sarcastic, or joking: "Yeah, he's a real rocket scientist!"

\subsection{Teaching and Learning English Speaking Skills}

According to Hornby (1995:37) teaching means giving the instruction to a person, giving a person knowledge, skills, etc, while learning means an activity of someone to improve their behavior, knowledge, skills so he becomes a better person. "Speaking" is the most attractive skill among others (Listening, Reading, Writing). In speaking, students are given the opportunity to develop their ability in an attractive way. According to Herrel and Jordan (2004:85), speaking gives students' confidence to interact and collaborate with other students. They communicate each other by using English verbally. The communication is building their ability in collaborating and sharing their ideas, responses, and solutions. In the speaking activities, students are given opportunities to have verbal communication practice among them. Students have the opportunity to discuss together, work together, and communicate together. In order to make an optimal interaction depends on how the teacher leads the students in the classroom activities, and it also much depends on the kinds of strategies he uses.

Teaching English speaking means to teach students to produce the English speech sounds, and sound pattern, using word and sentence stress, intonation pattern and the rhythm of the foreign language, select appropriate words and sentence according to the proper social setting, situations and object matter, organize their taught in a meaningful and logical sequence, use language as means of expressing values and judgments, use the language quickly and confidently with few unnatural pauses, which is called as fluency. Meanwhile, learning speaking means the activity of students to get knowledge of make use of words to communicate in appropriate situation in order to improve their knowledge.

Teaching and learning speaking skills means the activity of teacher in giving knowledge and student's activity in improving the knowledge of making use of word in an ordinary voice. Students should try to avoid confusion in the message due to faulty pronunciation, grammar or vocabulary and to observe the social and cultural rules that apply in each communication situation (NCLRC: 2004).

\subsection{Student Wheels Strategy}


Cooperative learning is a learning approach that focuses on the use of small groups of students to work together to maximize the learning conditions for achieving learning goals, and also the learning strategies that involve the participation of students in small groups to interact each other (Nurulhayati, 2002:25 in Rusman, 2010: 203). The concept of cooperative learning is to create a critical, lovely, and carely interaction in creating learning communities, and the students are not only learning from their teachers but also from their friends or other students.

Student Wheels is one of the learning strategies adopted by Jill Hadfield and Charles Hadfield (1999:12) to enable students in learning speaking. This strategy is suitable to be applied in a number of students more than 20 people. All students are involved in speaking activities because they can face their partners in asking and answering some questions each other. For example, when the number of students in a class of 40 students, of course each circle will be in 20 students, 20 will be in the outer circle and 20 will be in the inner circle. The shape formation in this strategy likes a wheel.

In this student wheels strategy, each student gets their own spouses to converse in a circle formation which formed two layers, then each student in each circle should shift one step and get a new pair to chat again. Once students have a conversation with their partner, they will be asked to move each one step to the left so that they get a different pair of interviews than first one. In this activity the students who are in the inner circles will ask questions while the partners on the outside circles will aswer those questions. Once the interview is completed, students are required to present the results of an interview in a big circle formed by the whole number of students there and commented on by other students. So no one of the students will not involve in the speaking activity.

Before applying the Student Wheels, of course the students are provided the informations how to make sentences or phrases that are being studied, such as the phrases of asking, giving, accepting or rejecting the invitation, services, goods, and so on.

\section{Method of the Study}

This research was limited to a second-grade Junior High School classroom in Banjarmasin, South Kalimantan, so that a case study is appropriate to choose. The focus was on one classroom teacher as the researcher examined how the teacher promoted the student wheels strategy in teaching English speaking skills to cultivate the language politeness in the classroom through two cycles of action. This study use Classroom Action Research (CAR). Action research is an applied research that contributes to principle and theories and is also action-oriented. A problemsolving technique is used to improve conditions and processes of the real world (Alwasilah, 2011).

Action research differs from other research because the process is a cycle. The cycle leads research participants to new questions upon which they act, observe, and reflect, thus creating the cycle effect (Alwasilah, 2011). Throughout this study, two cycles had been conducted. The teacher acted the treatment and researcher acted as a passive observer. It can be drawn as on Figure 1 below.

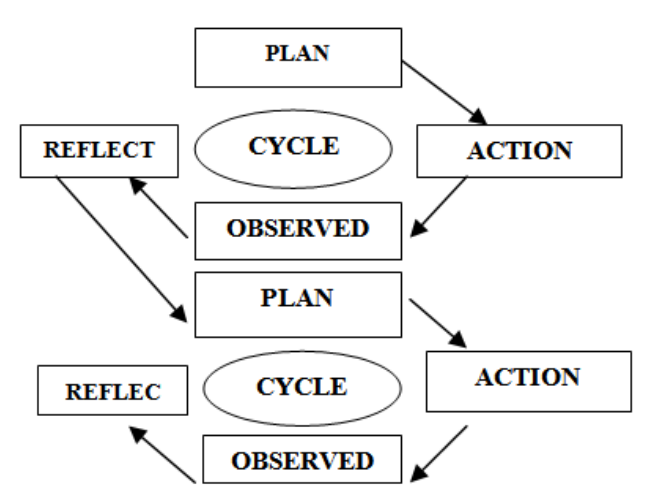

Figure 1. Action Research Model (Suharsimi, 2008:133)

This action research was a qualitative study. In qualitative research, the researcher strives to understand meaning constructed by people. The inductive process is richly descriptive and allows the researcher to be the primary instrument for data collection (Merriam, 1998 in Apriliaswati, 2011:63-64). For this research, a qualitative approach allowed the researcher to gather information using assorted resources. The researcher was able to triangulate information and draw from various resources to justify her conclusions and increase the validity.

Creswell (2008) states that document analysis consists of taking apart the data to determine individual responses and then summarizing it by putting it back together. In this study, the researcher analyzed the data from classroom observations, field notes, audiotape, photographs, conversations, and interviews.

By analyzing those data sources such as classroom observations, field notes, classroom document collection, and interviews through digital voice recordings, the researcher was able to interpret that cultivating language politeness in learning English speaking skills through student wheels strategy in the classroom was done successfully.

\section{Discussion}

\subsection{The Concept and the Application of the Politeness}

In everyday conversation, there are ways to go about getting the things we want. When we are with a group of friends, we can say to them, "Go get me that plate!", or "Shut-up!" However, when we are surrounded by a group of adults at a formal function, in which our parents are attending, we must say, "Could you please pass me that plate, if you don't mind?" and "I'm sorry, I don't mean to interrupt, but I am not able to hear the speaker in the front of the room." In different social situations, we are obligated to adjust our use of words to fit the occasion. It would seem socially unacceptable if the phrases above were reversed.

The values of the students linguistic politeness are formed by listening and learning from the people around them. Beside the family at home, the teacher is the closest person to the students and has a very big influence for them. Any teachers behavior whether good or bad, their politeness or impoliteness language will be imitated by students. Therefore, teachers need to implement a good attitude and behavior, as well as the polite language, 
especially in English lessons which students are much more influenced by impoliteness behavior or language shown by uneducated movies or other medias. Therefore, the task of English teachers are to explain, implement, and cultivate the language politeness by using polite expressions, whether inside or outside the classroom continuously. Any teachers efforts will be successful if they are always use polite language anytime as a good model in the classroom and also at school.

Parents and family at home are the primary responsibled in implementing courtesy and manners for their children. Then, teachers at school will continue to implement the politeness as well as the society. The three elements, according to Achir (2000: 43), should be done together harmoniously. Politeness and manners should be instilled in children as early as possible.

Linguistic politeness (speech) is reflected in the procedures to communicate through the verbal language signs. In communicating manners, the speaker and the hearer should pay attention to the cultural norms beside to convey the idea that we think only. If someone does not speak or obey the procedures in cultural norms, he will get a negative value, for example, accused of being arrogant, haughty, indifferent, self-centered, well-mannered, even uncivilized.

One of the main purposes of sociopragmatics is to find out how different people organize maxims based on their point of view and culture of giving politeness. In speech act communication, the term politeness refers to how to do face-work, that is the attempt to establish a good relationship during a conversation. Leech (1983:81) defines that in a conversation there is indirect information which is associated with indirect implicatures. Thus, this indirect implicatures is known as the Politeness Principle (PP).

Take one of Leech's examples (1983:80)

A: We'll all miss Bill and Agatha, won't we?

B: Well, we'll all miss Bill

In the exchange between A and B, B apparently fails to obey the Quantity Maxim because B only confirms part of A's opinion. B's statement implicates that both A and B will not miss Agatha. In truth, B conceals the desired information in order to support the Politeness Principle (PP).

Then, who should speak to courtesy? Theoretically, everyone should speak in a dignified manner. Everyone must communicate in order to maintain ethics in communication. Language is a tool of communication and the use of it must consider whether the rules of language as in the linguistic rules or the politeness rules can be achieved. It means that the use of rules of sound, form of words, sentence structure, and the English grammar must be correct in order to achieve the communication goes smoothly.

\subsection{Teaching and Learning English Speaking Skills at Junior High School}

Nowadays, our government has been applying the newest curriculum, namely School Based Curriculum (KTSP) as revision of curriculum 2004. It is stated in Government's Rule (Peraturan Pemerintah No 19/2005) which is also supported and issued in National Education Rule (Peraturan Menteri Pendidikan Nasional RIl/ PERMENDIKNAS RI No 24/2006). Each language skills has own standard competence and basic competence. For example, in standard competence for speaking skills at eight grade students of junior high school are required to be able to use simple expression in transactional and interpersonal interaction. Besides, they are required to be able to express simple short meanings functionally and monologue in form of descriptive and recount.

Simple expression in transactional and interpersonal interaction include asking, offering and declining offers; asking, giving and declining things; accepting and rejecting a fact; asking and giving opinion; making, accepting and refusing invitation; agreeing and disagreeing; praise and congratulation (Depdiknas, 2007:45). Nunan (2005:97) explains transactional speech involves communicating to get something done, such as the exchange of goods and/or service. Interpersonal speech is communication for social purpose, including stabling and maintaining social relationships. Drill, dialogue, interview and role play are activities which use in their teaching and learning activities. Meanwhile, the simple short meanings functionally and monologue in form of descriptive and recount which include the activities of making invitation, telling an event, retelling a story or passage, and discussing about information in a recount text (Depdiknas, 2007: 48).

Students need to know how speakers differ from one another and how particular circumstances call for different forms of speech. They can learn how speaking styles affect listeners. Thus, the rate at which they speak, the volume and the precision of pronunciation may differ substantially from one situation to another. It is useful for students to know that speech should differ in formality, such as when speaking to a judge, a teacher, a parent or a playmate. They may also benefit from learning about the differences among various dialects. The subjects in the curriculum and examples from the media may provide occasions for different forms of speech.

\subsection{Implementation of Politeness in Teaching Speaking}

As mentioned on the introduction that actually on the syllabus of teaching speaking skills has already contained of the ethical values or politeness principle. But the teacher still teach the knowledge how to use the expressions mentioned on the indicators of basic competence only without implementing the ethical values of that expression clearly. The writer gives the example of one Standard Competence and Basic Competence of Speaking taught at the eighth grade of junior high school as viewed on Table 1 below:

Table 1. Standard Competence and Basic Competence of SMP

\begin{tabular}{|c|c|}
\hline Standard Competence: Speaking & Basic Competence \\
\hline $\begin{array}{c}\text { Revealing the meaning in short verbal simple } \\
\text { transacsional and interpersonal conversations to } \\
\text { interact with the environment }\end{array}$ & $\begin{array}{c}\text { 3.1 Revealing the meaning in transacsional (to get Things Done) and interpersonal (social) } \\
\text { conversations by using a variety of simple spoken language accurately, fluently, and acceptable } \\
\text { to interact with the environment that involve speech acts: asking, giving, refusing service, } \\
\text { asking, giving, reject the goods, admitting, denying the facts, and ask for and giving opinion. }\end{array}$ \\
\hline
\end{tabular}


From that syllabus, the teacher should develop the teaching material based on the topic as mentioned on Table 2 below:

Table 2. Teaching Material

\begin{tabular}{|c|c|}
\multicolumn{2}{c|}{ Table 2. Teaching Material } \\
\hline No. & Topic/ Teaching Material \\
\hline 1. & Asking, giving, and refusing opinion \\
2. & Asking, giving and denying information \\
3. & Asking, giving, and refusing service \\
4. & Asking, giving, and rejecting the goods \\
\hline
\end{tabular}

The writer take one of the teaching material, "Asking, giving, and refusing opinion", which have some expressions learned by the students, such as shown on Table 3:

Table 3. Asking and Responding Opinions

\begin{tabular}{|c|c|}
\hline Asking opinions & Responding opinions \\
\hline Do you think it is good? & I think it is. \\
What do you think about his work? & Sorry, I can't say anytrhing. \\
What do you think if you stay in my & I think it's very nice, but I'm \\
house? & sorry I can't. \\
Do you think it's allright if I move your & Sure, with pleasure. \\
car near to the Mosque? & Sorry, I won't be at home \\
May I come to your house tonight? & tonight. \\
\hline
\end{tabular}

Then, ask students to divide into two groups to make two circles in front of the class. They have to use the English polite expressions which have discussed before. They form a formation like a wheel, 10 students will be in the outer circle and 10 others are in the inner circle. If the number of students in a class of 40 students, of course in each circle will be 20 students. The shape formation in this model can be seen in Figure 2 below:

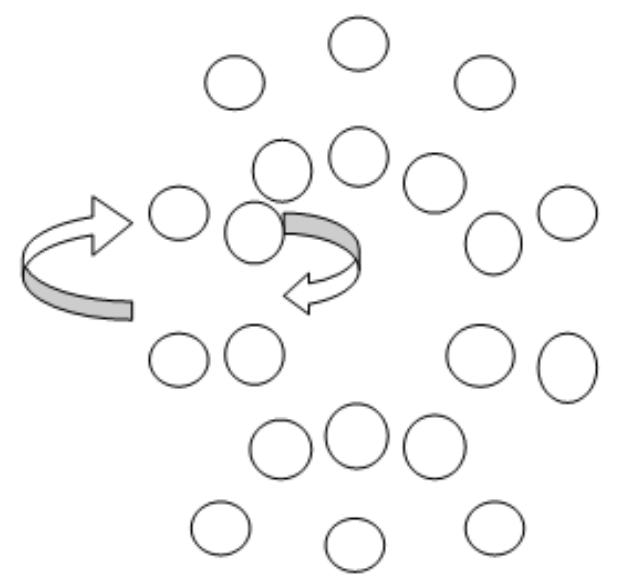

Figure 2. Students Wheel formation with small circles in 2 layer, the students face each other

Each student gets their own spouses to converse in a circle formation which formed two layers, then each student in each circle should shift one step and get a new pair to chat again. Once, students have a conversation with their partner, they will be asked to move each one step to the left so that they get a different pair of interviews than the first one. In this activity the students who are in the inner circles will ask questions while the partners on the outside circles aswer those questions.

After having cultivated the students' politeness by using student wheels strategy, the teacher gives model of conversation in using those expressions and ask students to read and perform the model.

The models are:

Dimas meets his friend, Rizal in front of a coffee shop.

Dimas: Hi, Rizal. How are you?
Rizal: Fine, thanks. And you?

Dimas: O.K. By the way, what do you think if we have a cup of coffee?

Rizal: I'd love it, but I'm so sorry I can't, cause I've to go home soon.

Dimas: Well, may be next time.

2. Two neighbors begin talking in their backyards.

Nancy: Mary. What are you doing? You look so busy.

Mary: Oh, hi! My mother will visit me next Friday so I've to prepare a room for her.

Nancy: May I help you?

Mary: With pleasure, thank you.

Nancy: Don't mention it. We're neighbour.

After performing the model, the students are asked to work in groups to arrange dialogues using polite expressions they have learned and performed before. Then, they can perform their owned dialogues in front of the class.

Some of the students' dialogues prepared in groups and performed them can be shown below.

From the expressions learned in models above and the dialogues they have prepared, the teacher can implant the ethical values that how to refuse the speaker's opinion politely and nicely. It means that the teacher is not only teaching the cognitive domain but also teaching the affective domain as well.

\section{Closed}

The Indonesian, who believes strongly in politeness in language, will be conveyed the meaning, not only related to the selection of words, but also how its delivery as well. For example; when someone deliver the selected words in rude manners, it's still impressed impolite expression. Politeness is very important in everyone's life because they believe that politeness implementation can reflect the culture of a society.

Although politeness in English is different as the Indonesian language, but politeness is also used in English, especially how one's attitude in uttering his speaking, respect the other person or the listener by keeping the eye contact, distance-spoken, and sincere smile without coercion.

Based on discussion above, can be concluded that teaching and learning English at school, especially junior high school, should consider the affective domain to be implant to the students. Because ethical values and politeness of students language is formed by looking and learning from people around them. Beside the family at home, a teacher is the person closest to the child or student and had an enormous influence. All the teachers' behavior good or bad, politeness or impoliteness will be imitated by students. Therefore, teachers need to apply the attitude and good manners, and polite language for a good students' personality formation.

By using student wheels strategy in teaching and learning English speaking skills, it can implement and cultivate politeness in English because all students can get a turn to speak and be able to use the English politeness expressions continuously so that they are accustomed in using English politeness expressions when they are speaking. 
Besides being able to cultivate students in using English politeness expressions, students can also be accustomed to hear other people talking or arguing before submitting comments or personal opinion as well. The students can also cooperate well, consider and respect someone opinions, and ask some opinion in polite speech, and always be able to choose appropriate vocabulary (diction) in any situation.

To keep the ethical values and English politeness implemented, the English teachers at Junior High Schools (SMP) should implement it at their teaching, especially in English speaking class.

\section{References}

[1] Alwasilah, A.C., Filsafat Bahasa dan Pendidikan. Bandung: PT Remaja Rosdakarya, 2008, 24-25.

[2] Apriliaswati, Rahayu, Promoting Peer Interactions to Develop Positive Civil Discourse. (A Case Study of Action Research at Elementary School 42 Pontianak) Disertasi. Bandung: Universitas Pendidikan Indonesia. 2011.

[3] Austin, J.L, How to Do Thing with Words. Cambridge, Mass: Harvard U.P., 1962.

[4] Brown, Penelope and Stephen C. Levinson. Politeness Some Universals in Language Usage. Cambridge University Press, 1998, 80.

[5] Chaer, Abdul, Kesantunan Barbahasa. Jakarata: Rineka Cipta, 2010, 6-9

[6] Coulthard, M, An Introduction to Discourse Analysis. New York: Longman Inc, 1985, 18-19.
[7] Creswell, John W, Educational Research: Planning, Conducting, and Evaluating Quantitative and Qualitative Research. Boston: Pearson, 2008, 580-581.

[8] Hadfield, Jill dan Charles Hadfield, Simple Speaking Activity. New York: Oxford University Press, 1999, 19-20.

[9] Halliwell, Susan. 1994. Teaching English in The Primary Classroom. London and New York: Longman, 1994, 38.

[10] Leech, N., Geoffrey, Principles of Pragmatics. London and New York: Longman Group Ltd, 1983, 34.

[11] Levinson, C., Stephen, Pragmatics. London: Cambridge University Press. 1985, 49-52.

[12] Lickona, Thomas, Educating for Character, How Our Schools can Teach Respect and Responsibility. Bantam Books, New York, 1991, 51-52.

[13] Mariani, Nanik, Conversational Implicatures in Bernard Shaw's "Pygmalion". Unpublished thesis. Malang: State University of Malang, 2003, 28.

[14] Megawangi, R, Pendidikan Karakter, solusi yang tepat untuk membangun bangsa. Jakarta: BP. Migas, 2004, 95.

[15] Muslich, Masnur, Kesantunan Berbahasa. Suatu Kajian Sosiolinguistik. Malang: UM Press, 2006, 26.

[16] Prayitno dan Belferik Manullang, Pendidikan Karakter dalam Pembangunan Bangsa. Medan: Penerbit Pascasarjana Universitas Negeri Medan, 2011, 38-39.

[17] Sauri, Sofyan, Pendidikan Berbahasa Santun. Bandung: PT Genesindo, 2006, 51-52.

[18] Searle, J. R., Ference Kiefer \& Manfred Bierwisch, Speech Act Theory and Pragmatics. London: D. Reidel Publishing Company, 1975, 19-2

[19] Sulistiyowati, Ari, Peningkatan Kemampuan Speaking melalui Pembelajaran yang Menyenangkan dengan Model Student Wheels pada Kelas VIIC SMP Negeri 2 Mirit Tahun Pelajaran 2007/2008. Widyatama Journal, 6 (1). 69-77, March 2009.

[20] Watts, Richard J, Politeness. United Kingdom: Cambridge University Press, 2003, 1-2. 